Volume 6 No. 2, September 2018

P-ISSN: 2337-9251, E-ISSN: 2597-9094

Open Access at : http://jurnal.umt.ac.id/index.php/replik/article/view/1442

\title{
RELEVANSI ALAT BUKTI INFORMASI ELEKTRONIK DALAM HUKUM ACARA PIDANA DI INDONESIA
}

\author{
Abdul Kadir \\ Fakultas Hukum Universitas Muhammadiyah Tangerang \\ E-mail : abdulkadir.usman87@yahoo.com
}

\begin{abstract}
Abstrak
Perkembangan teknologi informasi mengakibatkan perkembangan tindak pidana dalam hal dunia maya atau biasa disebut cyber crime. Permasalahan Relevansi alat bukti informasi elektronik dalam hukum acara pidana di Indonesia dan perkembangan alat bukti informasi elektronik menjadi permaslahan yang diangkat dalam penelitian ini. Jenis penelitian ini adalah penelitian hukum normatif, yaitu penelitian yang berfokus pada hukum positif yang berupa pengaturan perundangundangan. Relevansi alat bukti informasi elektronik sebagai alat bukti yang sah telah diakui dengan keluarnya Undang-Undang Nomor 11 Tahun 2008 tentang Informasi dan Transaksi Elektronik. Alat bukti informasi elektronik di Indonesia sebenarnya sudah diatur Undang-Undang Nomor 8 Tahun 1997 tentang Dokumen Perusahaan yang aman di dalamnya terkait dengan dokumen elektronik.
\end{abstract}

Kata Kunci : Alat Bukti, Relevansi, Informasi Elektronik. 


\section{PENDAHULUAN}

Aturan hukum ditentukan berdasarkan hak dan kewajiban termasuk larangan dan anjuran bagi setiap orang atau warga Negara. Pasal 1 Ayat (3) Undang-Undang Dasar Negara Republik Indonesia Tahun 1945 menjelaskan bahwa setiap warga negaranya di atur oleh hukum. Sebagaimana yang dikonsepkan oleh Sri Soemantri bahwa Negara hukum dalam melaksanakan tugas dan kewajiban harus berdasarkan hukum dan konstitusi, adanya pembagian kekuasaan, adanya jaminan terhadap hak-hak manusia dan adanaya badan pengawas terkait peradilan. ${ }^{1}$ Untuk mengatur tindakan warga negaranya aturan tersebut harus dibedakan baik secara materil dan juga formil. Aturan hukum secara materil atau biasa disebut oleh kita adalah hukum pidana sedangkan hukum secara formil sendiri adalah bagaimana beracara atau disebut hukum acara pidana. Keduanya memiliki hubungan yang sangat erat seperti pidana mengatur tata cara bagaimana negara menggunakan haknya untuk melakukan penghukuman dalam perkara-perkara yang terjadi sedangkan Hukum acara pidana adalah bagaimana menjalankan hukum pidana materil atau bagaimana beracara dalam hal kekuasaan kehakiman. ${ }^{2}$

Guna memperoleh suatu kebenaran dan keyakinan terkait benar tidaknya suatu perbuatan pidana yang didakwakan pada diri terdakwa dibutuhkan sebuah pembuktian yang bisa didapatkan dengan alat-alat bukti dan barang bukti sebagai suatu upaya untuk mendapatkan keterangan. ${ }^{3}$ Untuk menemukan suatu fakta dipersidangan Relevansi alat bukti adalah sesuatu yang pertama harus diputuskan oleh hakim dan hal ini menjadi alasan untuk diterima atau ditolaknya suatu alat bukti.

Sistem informasi yang merupakan penerapan teknologi informasi yang berbasis jaringan telekomunikasi dan media elektronik berimbas semakin beragam dan canggihnya produk teknologi informasi. Perkembangan teknologi informasi tidak mengurangi perkembangan tindak pidana seperti kejahatan dalam hal dunia maya atau biasa disebut cyber crime. Kejahatan-kejahatan tersebut secara langsung

\footnotetext{
${ }^{1}$ Mien Rukmini, Perlindungan HAM Melalui Asas Praduga Tidak Bersalah Dan Asas Persamaan Kedudukan Dalam Hukum Pada Sistem Peradilan Pidana Indonesia (Bandung: Alumni, 2003), hlm.1.

${ }^{2}$ Djoko Prakoso, Alat Bukti dan Kekuatan Pembuktian di dalam Proses Pidana (Yogyakarta: Liberty, 1988), hlm. 1. 2007), hlm. 185

${ }^{3}$ Rusli Muhammad, Hukum Acara Pidana Kontemporer (Jakarta: Citra Aditya Bakti,
} 
membutuhkan sebuah bukti dalam persidangan dan berakibat kepada alat bukti baru dalam proses pembuktian. Dalam KUHAP sendiri tidak menjelaskan bahwa alat bukti dalam kejahatan cyber crime tidak tercantum sehingga penerapannya sulit untuk dilaksanakan dalam hal pembuktikan kesalahan terdakwa.

Secara politik hukum Negara membuat sebuah terobosan baru dalam hal regulasi terkait kejahatan dunia maya (cyber crime) dengan diterbitkannya UndangUndang Nomor 11 Tahun 2008 dan dirubah pada tahun 2016 menjadi UndangUndang Nomor 19 Tahun 2016 tentang Informasi dan Transaksi Elektronik. Dengan adanya regulasi ini keberadaan alat bukti informasi elektronik mulai diakui dan dipergunakan dalam hukum acara di Indonesia.

Terkait hal ini penulis tertarik untuk mengkaji lebih dalam sebuah tulisan ilmiah sederhana dengan judul Relevansi Alat Bukti Informasi Elektronik Dalam Hukum Acara Pidana Di Indonesia. Dengan permasalahan sebagai berikut :

A. Bagaimana relevansi alat bukti informasi elektronik dalam hukum acara pidana di Indonesia?

B. Bagaimana perkembangan alat bukti informasi elektronik di Indonesia ?

\section{METODE PENELITIAN}

Jenis penelitian ini adalah penelitian hukum normatif, yaitu penelitian yang berfokus pada hukum positif yang berupa pengaturan perundang-undangan dan penelitian ini memerlukan bahan hukum sekunder sebagai data utama. Teknik pengumpulan data dilakukan dengan cara studi kepustakaan, yaitu suatu cara untuk mengumpulkan data yang berupa buku, dan sumber-sumber resmi yang terkait dengan permasalahan hukum yang diteliti. Pengolahan data menggunakan analisis kualitatif, yaitu dengan cara menganalisis hasil penelitian dengan data deskriptif analisis.

\section{HASIL PENELITIAN DAN ANALISIS}

\section{A. Relevansi Alat Bukti Informasi Elektronik Dalam Hukum Acara Pidana di Indonesia \\ Pembuktian memegang peranan yang sangat penting dalam proses pemeriksaan sidang pengadilan, karena dengan pembuktian inilah nasib terdakwa}


ditentukan, dan hanya dengan pembuktian suatu perbuatan pidana dapat dijatuhi hukuman pidana. Pembuktian adalah ketentuan-ketentuan yang berisi penggarisan dan pedoman tentang cara-cara yang dibenarkan undang-undang untuk membuktikan kesalahan yang didakwakan kepada terdakwa. Pembuktian juga merupakan ketentuan yang mengatur alat-alat bukti yang dibenarkan undangundang dan boleh dipergunakan hakim membuktikan kesalahan yang didakwakan. ${ }^{4}$ Pengertian tentang pembuktian dalam KUHAP tidak diatur secara jelas, namun hanya menerangkan jenis-jenis alat bukti yang sah menurut hukum yang tertuang dalam pasal 184 Ayat (1). Jenis alat bukti yang sah dan dapat digunakan sebagai alat bukti menurut Pasal 184 Ayat (1) KUHAP adalah :

1. Keterangan saksi;

2. Keterangan ahli;

3. Surat;

4. Petunjuk;

5. Keterangan terdakwa.

Meskipun KUHAP tidak memberikan pengertian tentang pembuktian, namun demikian banyak ahli hukum yang memberikan pendapatnya dalam menjelaskan pengertian pembuktian. Menurut Adam Chazawi, hukum pembuktian adalah memuat dan mengatur tentang berbagai unsur pembuktian yang tersusun dan teratur saling berkaitan dan berhubungan sehingga membentuk suatu kebulatan perihal pembuktian. ${ }^{5}$

Jadi dapat dimaksudkan bahwa membuktikan berarti meyakinkan hakim tentang kebenaran dalil yang dikemukakan oleh para pihak dalam suatu sengketa. Dalam perkembangan hukum acara pidana menunjukan bahwa ada beberapa sistem atau teori untuk membuktikan perbuatan yang didakwakan. Dalam menilai kekuatan pembuktian alat-alat bukti yang ada dikenal beberapa sistem atau teori pembuktian.

1. Sistem atau teori pembuktian berdasarkan undang-undang secara positif (Positive Wettelijk Bewijstheori)

${ }^{4}$ M. Yahya Harahap, Pembahasan Permasalahan dan Penerapan KUHAP Pemeriksaan Sidang Pengadilan, Banding, Kasasi, dan Peninjauan Kembali (Jakarta : Sinar Grafika, 2012), hlm. 273.

${ }^{5}$ Adam Chazawi, Hukum Pembuktian Tindak Pidana Korupsi, (Bandung : Alumni, 2008), hlm. 24. 
Pembuktian yang didasarkan melulu kepada alat-alat pembuktian yang disebut undang-undang, disebut dengan sistem atau teori pembuktian berdasar undang-undang secara positif (positief wettelijk bewijstheorie). Dikatakan secara positif, karena hanya didasarkan kepada undang-undang melulu. Artinya, jika telah terbukti suatu perbuatan sesuai dengan alat-alat bukti yang disebut oleh undang-undang, maka keyakinan hakim tidak diperukan sama sekali. ${ }^{6}$

2. Sistem atau teori pembuktian berdasarkan keyakinan hakim melulu

Teori pembuktian berdasarkan keyakinan hakim melulu yang disebut juga conviction intime. Teori ini didasarkan kepada keyakinan hati nurani hakim sendiri ditetapkan bahwa terdakwa telah melakukan perbuatan yang didakwakan. $^{7}$

3. Sistem atau teori pembuktian berdasarkan keyakinan hakim atas alasan yang logis (Laconviction Raisonnee)

Menurut teori ini, hakim dapat memutuskan seseorang bersalah berdasarkan keyakinannya, keyakinan yang didasarkan kepada dasar-dasar pembuktian disertai dengan suatu kesimpulan (conclusive) yang berlandaskan kepada peraturan-peraturan pembuktian tertentu. ${ }^{8}$

4. Teori pembuktian berdasarkan undang-undang secara negatif (Negatief

\section{Wettelijk)}

Dalam sistem atau teori pembuktian berdasarkan undang-undang secara negatif ini, pemidanaan didasarkan kepada pembuktian yang berganda, yaitu peraturan perundang-undangan dan pada keyakinan hakim, dan menurut undang-undang, dasar keyakinan hakim itu bersumberkan pada peraturan perundang-undangan. ${ }^{9}$

Sistem pembuktian yang dianut dan diatur dalam KUHAP adalah pembuktian menurut undang-undang secara negatif. Hal ini sebagaimana pasal 183 KUHAP yakni:

\footnotetext{
${ }^{6}$ Andi Hamzah, Hukum Acara Pidana Indonesia (Jakarta : Sinar Grafika, 2016), hlm.
} 251.

${ }^{7}$ Andi Hamzah, Ibid. hlm. 252.

${ }^{8}$ Andi Hamzah, Ibid. hlm. 253.

${ }^{9}$ Andi Hamzah, Ibid. hlm. 256. 
"Hakim tidak boleh menjatuhkan pidana kepada seseorang kecuali apabila dengan sekurang-kurangnya dua alat bukti yang sah ia memperoleh keyakinan bahwa suatu tindak pidana benar-benar terjadi dan bahwa terdakwalah yang bersalah melakukannya".

Dengan demikian pasal 183 KUHAP mengatur, untuk menentukan salah atau tidaknya seorang terdakwa dan untuk menjatuhkan pidana kepada terdakwa, harus: ${ }^{10}$

1. Kesalahan terbukti dengan sekurang-kurangnya dua alat bukti yang sah.

2. Dan atas keterbuktian dengan sekurang-kurangnya dua alat bukti yang sah, hakim memperoleh keyakinan bahwa tindak pidana benar-benar terjadi dan bahwa terdakwalah yang bersalah melakukannya.

Dalam teori pembuktian negatif, secara prinsip teori pembuktian menurut hukum, seseorang dapat dinyatakan bersalah atau tidak manakala pembuktian harus menggunakan alat bukti yang sah menurut undang-undang serta keyakinan hakim juga harus berdasarkan alat bukti yang sah menurut undang-undang.

Teori hukum pembuktian mengajarkan bahwa suatu alat bukti dapat dipakai sebagai alat bukti di pengadilan diperlukan beberapa syarat-syarat sebagai berikut : ${ }^{11}$

1. Diperkenankan oleh undang-undang untuk dipakai sebagai alat bukti.

2. Reability, yakni alat bukti tersebut dipercaya keabsahannya (misalnya, tidak palsu).

3. Necessity, yakni alat bukti tersebut memang diperlukan untuk membuktikan suatu fakta.

4. Relevance, yakni alat bukti tersebut mempunyai relevansi dengan fakta yang akan dibuktikan.

Relevansi alat bukti adalah hal yang pertama harus diputuskan oleh hakim dalam pembuktian di persidangan. Agar suatu alat bukti dapat diterima, maka hakim harus memastikan alat bukti yang diajukan oleh para pihak di persidangan relevan dengan apa yang akan dibuktikan.

\footnotetext{
${ }^{10}$ M. Yahya Harahap, Pembahasan Permasalahan dan Penerapan KUHAP Pemeriksaan Sidang Pengadilan, Banding, Kasasi, dan Peninjauan Kembali (Jakarta : Sinar Grafika, 2012), hlm. 280.

${ }^{11}$ Munir Fuady, Teori Hukum Pembuktian Pidana dan Perdata (Bandung : Citra Aditya Bakti, 2012), hlm. 4.
} 
Relevan atau tidaknya suatu alat bukti, maka haruslah dicari tahu dengan menjawab pertanyaan-pertanyaan sebagai berikut $:^{12}$

1. Apakah yang akan dibuktikan oleh alat bukti tersebut?

2. Apakah yang akan dibuktikan itu merupakan hal yang material/substansial bagi kasus tersebut?

3. Apakah bukti tersebut memiliki hubungan secara logis dengan masalah yang akan dibuktikan ?

4. Apakah bukti tersebut cukup menolong menjelaskan persoalan (cukup memiliki unsur pembuktian) ?

Penentuan relevan atau tidaknya suatu alat bukti merupakan kewenangan hakim yang memutuskannya. Oleh karena itu, penting untuk diketahui oleh hakim sejauh mana suatu alat bukti relevan dengan kasus yang bersangkutan. Hal ini karena menerima bukti yang tidak relevan akan mengandung resiko-resiko tertentu, yaitu sebagai berikut: ${ }^{13}$

1. Membuang-buang waktu sehingga dapat memperlambat proses peradilan.

2. Dapat menjadi misleading yang menimbulkan praduga-praduga yang tidak perlu.

3. Penilaian terhadap masalah tersebut tidak proposional, dengan membesarbesarkan yang sebenarnya kecil atau mengecil-ngecilkan yang sebenarnya besar.

4. Membuat proses peradilan menjadi tidak rasional.

Sebagaimana yang diuraikan di atas, Pasal 184 Ayat (1) KUHAP telah menentukan secara limitatif alat bukti yang sah menurut undang-undang. Di luar alat bukti itu, tidak dibenarkan dipergunakan untuk membuktikan kesalahan terdakwa. Ketua sidang, penuntut umum, terdakwa atau penasihat hukum, terikat dan terbatas hanya diperbolehkan mempergunakan alat-alat bukti itu saja. Mereka tidak leluasa mempergunakan alat bukti yang dikehendakinya di luar alat bukti yang ditentukan Pasal 184 Ayat (1) KUHAP. Yang dinilai sebagai alat bukti, dan yang dibenarkan mempunyai kekuatan pembuktian hanya terbatas kepada alat-alat bukti itu saja. Pembuktian di luar jenis alat bukti yang disebutkan Pasal 184 Ayat

\footnotetext{
${ }^{12}$ Munir Fuady, Ibid. hlm. 26.

${ }^{13}$ Munir Fuady, Ibid. hlm. 43.
} 
(1) KUHAP tidak mempunyai nilai serta tidak mempunyai kekuatan pembuktian yang mengikat. ${ }^{14}$

Masyarakat yang berkembang mengikuti perkembangan teknologi sehingga penggunaan alat teknologi digital dalam kehidupan bermasyarakat makin massif dalam segala hal, bahkan hampir seluruh bidang kehidupan menggunakan informasi elektronik.

Pemakaian internet dan bisnis melalui internet dewasa ini berkembang sangat pesat sehingga sektor hukum, termasuk hukum pembuktian, diminta untuk turun tangan sehingga bisnis melalui internet (e-commerce) dapat dicapai ketertiban dan kepastian, di samping tercapai pula unsur keadilan bagi para pihak. Menurut Munir Fuady yang dimaksud e-commerce adalah suatu proses berbisnis dengan memakai teknologi elektronik yang menghubungkan antara perusahaan, konsumen, dan masyarakat dalam bentuk transaksi elektronik, dan pertukaran/penjualan barang, servis, dan informasi secara elektronik. ${ }^{15}$

Masalah hukum tentang e-commerce belum dapat diakui, baik sebagai bukti oleh hukum secara konvensional di dalam KUHAP. Beberapa prinsip hukum yang bersentuhan dengan e-commerce yang mestinya diakui sektor hukum pembuktian adalah sebagai berikut $:^{16}$

1. Semua informasi elektronik dalam bentuk data elektronik mestinya memiliki kekuatan hukum sehingga mempunyai kekuatan pembuktian. Dengan demikian, data elektronik mestinya mempunyai kekuatan pembuktian yang sama dengan dokumen kertas.

2. Kontrak yang dibuat secara elektronik mempunyai akibat hukum dan kekuatan pembuktian yang sama dengan kontrak yang dibuat secara tertulis di atas kertas.

3. Tanda tangan elektronik mestinya mempunyai kekuatan pembuktian yang sama dengan tanda tangan biasa.

Informasi elektronik menurut Pasal 1 Ayat (1) Undang-Undang Nomor 11 Tahun 2008 tentang Informasi dan Transaksi Elektronik adalah satu atau sekumpulan data elektronik, termasuk tetapi tidak terbatas pada tulisan, suara,

\footnotetext{
${ }^{14}$ M. Yahya Harahap, Op.Cit. hlm. 285.

${ }^{15}$ M. Yahya Harahap, Op.Cit. hlm. 152.

${ }^{16}$ M. Yahya Harahap, Ibid. hlm. 155.
} 
gambar, peta, rancangan, foto, electronic data interchange (EDI), surat elektronik (electronic mail), telegram, teleks, telecopy atau sejenisnya, huruf, tanda, angka, kode akses, simbol, atau perforasi yang telah diolah yang memiliki arti atau dapat dipahami oleh orang yang mampu memahaminya.

Alat bukti informasi elektronik sebagai alat bukti sebelum keluarnya Undang-Undang Nomor 11 Tahun 2008 tentang Informasi dan Transaksi Elektronik dalam hukum acara pidana belum mempunyai status yang jelas. Termasuk juga penggunaan alat bukti informasi elektornik sangat rendah. Penggunaan informasi elektronik sebagai alat bukti di pengadilan masih dipertanyakan relevansi dan validitasnya. Proses pembuktian pada kasus cyber crime pada dasarnya tidak berbeda dengan pembuktian pada kasus konvensional.

Alat bukti informasi elektronik dapat digunakan dalam persidangan sejauh alat bukti tersebut dapat di peroleh dan dibuktikan dalam persidangan. Alat bukti informasi elektronik merupakan perluasan dari alat bukti petunjuk dalam KUHAP yang dimana alat bukti informasi ini di perluas maknanya sesuai dengan perkembangan teknologi yang berkembang. Alat bukti informasi elektronik merupakan alat bukti yang tidak dapat berdiri sendiri, namun harus didukung dengan alat bukti yang lain, sehingga dapat diterima sebagai alat bukti yang sah dalam persidangan.

Dengan diberlakukannya Undang-Undang Nomor 11 Tahun 2008 tentang Informasi dan Transaksi Elektronik, maka informasi elektronik dijadikan sebagai alat bukti yang sah dalam hukum acara pidana. Sebagaimana Pasal 5 ayat (1) Undang-Undang Nomor 11 Tahun 2008 tentang Informasi dan Transaksi Elektronik yang menyatakan bahwa informasi elektronik dan/atau dokumen elektronik dan atau hasil cetaknya merupakan alat bukti yang sah.

Pasal 5 ayat (2) Undang-Undang Nomor 11 Tahun 2008 tentang Informasi dan Transaksi Elektronik menyebutkan bahwa informasi elektronik dan/atau dokumen elektronik dan/atau hasil cetaknya sebagaimana dimaksud pada ayat (1) merupakan perluasan dari alat bukti yang sah sesuai dengan hukum acara yang berlaku di Indonesia.

Pemanfaatan dan penggunaan teknologi informasi dan transaksi elektronik yang dalam hal ini informasi elektronik sebai alat bukti dilaksanakan berdasarkan 
asas kepastian hukum, manfaat, kehati-hatian, itikad baik, dan kebebasan memilih teknologi atau netral teknologi sebagaimana Pasal 3 Undang-Undang Nomor 11 Tahun 2008 tentang Informasi dan Transaksi Elektronik.

Relevansi alat bukti informasi elektronik sebagai alat bukti yang sah akan memberikan manfaat sebagaimana Pasal 4 Undang-Undang Nomor 11 Tahun 2008 tentang Informasi dan Transaksi Elektronik, dengan tujuan untuk :

1. Mencerdaskan kehidupan bangsa sebagai bagian dari masyarakat informasi dunia;

2. Mengembangkan perdagangan dan perekonomian nasional dalam rangka meningkatkan kesejahteraan masyarakat;

3. Meningkatkan evektifitas dan efisiensi pelayanan publik;

4. Membuka kesempatan seluas-luasnya kepada setiap orang untuk memajukan pemikiran dan kemampuan di bidang penggunaan dan pemanfaatan teknologi informasi seoptimal mungkin dan bertanggungjawab; dan

5. Memberikan rasa aman, keadilan, dan kepastian hukum bagi pengguna dan penyelenggara teknologi informasi.

Penggunaan alat bukti informasi elektronik dalam hukum acara pidana setelah keluarnya Undang-Undang Nomor 11 Tahun 2008 tentang Informasi dan Transaksi Elektronik memiliki kekuatan hukum yang sama dengan proses pembuktian. Jadi informasi elektronik digunakan sebagai alat bukti yang sah dalam proses acara pidana di Indonesia, yakni alat bukti tersebut mempunyai relevansi dengan fakta yang akan dibuktikan dan diperkenankan oleh undang-undang untuk dipakai sebagai alat bukti.

\section{B. Perkembangan Alat Bukti Informasi Elektronik Di Indonesia}

Disahkannya Undang-Undang Nomor 11 Tahun 2008 tentang Informasi dan Transaksi Elektronik, maka bukti informasi elektronik telah diakui sebagai alat bukti yang sah sehingga dapat digunakan dalam melakukan pembuktian.

Beberapa Negara di dunia ini yang sudah mengadopsi perkembangan teknologi digital ke dalam hukum pembuktiannya sebelum Undang-Undang Nomor 11 Tahun 
2008 tentang Informasi dan Transaksi Elektronik diberlakukan di Indonesia, seperti .17

1. Hongkong telah memiliki Undang-Undang tentang Transaksi Elektronik sejak tanggal 7 Januari 2000.

2. Inggris telah memiliki the Electronic Communication Bill sejak tanggal 26 Januari 2000.

3. Jepang telah memiliki Undang-Undang tentang Tanda Tangan Elektronik dan Notarisasi Bisnis Nomor 102, tanggal 31 Mei 2000, yang mulai berlaku sejak tanggal 1 April 2001.

Kedudukan alat bukti informasi elektronik sebagaimana Pasal 5 UndangUndang Nomor 11 Tahun 2008 tentang Informasi dan Transaksi Elektronik, beberapa peraturan perundang-undangan hukum pidana yang menerangkan tentang alat bukti elektronik. Diantaranya $:^{18}$

1. Undang-Undang Nomor 8 Tahun 1997 tentang Dokumen Perusahaan.

2. Undang-Undang Nomor 20 Tahun 2001 tentang Perubahan Atas UndangUndang Nomor 31 Tahun 1999 tentang Pemberantasan Tindak Pidana Korupsi.

3. Undang-Undang Nomor 15 Tahun 2003 tentang Penetapan Peraturan Pemerintah Pengganti Undang-Undang Nomor 1 Tahun 2002 tentang Pemberantasan Tindak Pidana Terorisme, menjadi Undang-Undang.

4. Undang-undang nomor 21 tahun 2007 tentang Pemberantasan Tindak Pidana Perdagangan Orang.

5. Undang-Undang Nomor 35 Tahun 2009 tentang Narkotika.

6. Undang-Undang Nomor 8 Tahun 2010 tentang Pencegahan dan Pemberantasan Tindak Pidana Pencucian Uang.

7. Undang-Undang Nomor 9 Tahun 2013 tentang Pencegahan dan Pemberantasan Tindak Pidana Pendanaan Terorisme.

\footnotetext{
${ }^{17}$ Munir Fuady, Op.Cit. hlm. 155.

${ }^{18}$ Nur Laili Isma dan Arima Koyimatun, "Kekuatan Pembuktian Alat Bukti Informasi Elektronik Pada Dokumen Elektronik Serta Hasil Cetaknya Dalam Pembuktian Tindak Pidana" (Jurnal Penelitian Hukum, Volume 1, Nomor 2, Juli 2014, Universitas Gajah Mada, Jogjakarta), hlm. 111. https://jurnal.ugm.ac.id/jph/article/download/19104/12355. Diakses pada tanggal $30 \mathrm{Mei}$ 2018, Pukul 16.30 WIB.
} 
8. Undang-Undang Nomor 18 Tahun 2013 tentang Pencegahan dan Pemberantasan Perusakan Hutan.

9. Undang-undang Nomor 28 Tahun 2014 tentang Hak Cipta.

10. Undang-Undang Nomor 19 Tahun 2016 tentang Perubahan Atas UndangUndang Nomor 11 Tahun 2008 tentang Informasi dan Transaksi Elektronik.

11. Undang-Undang Nomor 20 Tahun 2016 tentang Merek dan Indikasi Geografis.

Dari Pasal 5 ayat (1) Undang-Undang Nomor 11 Tahun 2008 tentang Informasi dan Transaksi Elektronik yang menyatakan bahwa informasi elektronik dan/atau dokumen elektronik dan atau hasil cetaknya merupakan alat bukti yang sah. Jadi jelas kalau kita liat Undang-Undang Nomor 8 Tahun 1997 tentang Dokumen Perusahaan yang mana di dalamnya dokumen elektronik telah dipergunakan sebagai alat bukti, mengingat dokumen elektronik merupakan bagian dari dokumen perusahaan.

Undang-Undang tentang Pemberantasan Tindak pidana Korupsi yang dikeluarkan tahun 1999 serta Undang-Undang lainnya juga menjelaskan bahwasanya alat bukti informasi elektronik dipergunakan sebagai alat bukti yang sah sebagaimana Pasal 184 KUHAP yakni sebagai alat bukti petunjuk. Dan sampai saat ini penggunaan alat bukti informasi elektronik sudah mendapatkan pengakuan dan dipergunakan dalam setiap proses pembuktian hukum acara pidana di pengadilan.

\section{KESIMPULAN}

Penentuan relevan atau tidaknya suatu alat bukti merupakan kewenangan hakim yang memutuskannya. Oleh karena itu, penting untuk diketahui oleh hakim sejauh mana suatu alat bukti relevan dengan kasus yang bersangkutan. Alat bukti informasi elektronik dapat digunakan dalam persidangan sejauh alat bukti tersebut dapat di peroleh dan dibuktikan dalam persidangan. Alat bukti informasi elektronik merupakan perluasan dari alat bukti petunjuk dalam KUHAP yang dimana alat bukti informasi ini di perluas maknanya sesuai dengan perkembangan teknologi yang berkembang. Relevansi alat bukti informasi elektronik sebagai alat bukti yang 
sah telah diakui dengan keluarnya Undang-Undang Nomor 11 Tahun 2008 tentang Informasi dan Transaksi Elektronik.

Perkembangan alat bukti informasi elektronik di Indonesia sebenarnya sudah diatur Undang-Undang Nomor 8 Tahun 1997 tentang Dokumen Perusahaan yang aman di dalamnya terkait dengan dokumen elektronik. Kemudian dilanjutkan oleh Undang-Undang tentang Tindak Pidana Korupsi, tentang Terorisme, tentang Perdagangan Orang, tentang Tindak pidana Pencucian Uang, tentang Pencegahan dan Pemberantasan Perusakan Hutan, tentang Hak Cipta dan Merek, dan tentang Informasi dan Transaksi Elektronik.

\section{DAFTAR PUSTAKA}

\section{Buku:}

Chazawi, Adam. Hukum Pembuktian Tindak Pidana Korupsi. Bandung : Alumni, 2008.

Fuady, Munir. Teori Hukum Pembuktian Pidana dan Perdata. Bandung : Citra Aditya Bakti, 2012.

Hamzah, Andi. Hukum Acara Pidana Indonesia. Jakarta : Sinar Grafika, 2016.

Harahap, M. Yahya. Pembahasan Permasalahan dan Penerapan KUHAP Pemeriksaan Sidang Pengadilan, Banding, Kasasi, dan Peninjauan Kembali. Jakarta : Sinar Grafika, 2012.

Muhammad, Rusli. Hukum Acara Pidana Kontemporer. Jakarta: Citra Aditya Bakti, 2007.

Prakoso, Djoko. Alat Bukti dan Kekuatan Pembuktian di dalam Proses Pidana. Yogyakarta: Liberty, 1988.

Rukmini, Mien. Perlindungan HAM Melalui Asas Praduga Tidak Bersalah Dan Asas Persamaan Kedudukan Dalam Hukum Pada Sistem Peradilan Pidana Indonesia. Bandung: Alumni, 2003. 


\section{Jurnal:}

Nur Laili Isma dan Arima Koyimatun, Jurnal Penelitian Hukum “Kekuatan Pembuktian Alat Bukti Informasi Elektronik Pada Dokumen Elektronik Serta Hasil Cetaknya Dalam Pembuktian Tindak Pidana”. Volume 1, Nomor 2, Juli 2014, Universitas Gajah Mada, Jogjakarta. https://jurnal.ugm.ac.id/jph/article/download/19104/12355.

\section{Undang-Undang:}

Undang-Undang Nomor 11 Tahun 2008 tentang Informasi dan Transaksi Elektro 